
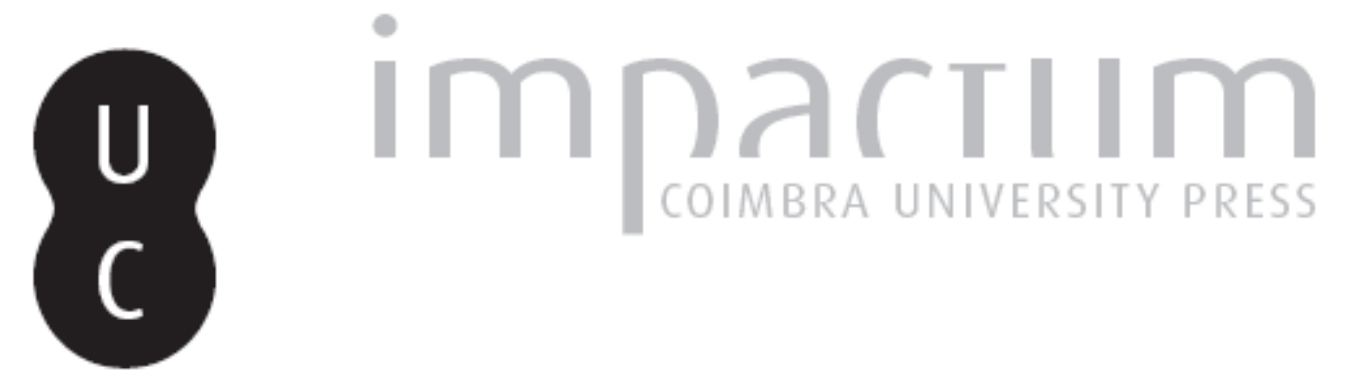

\title{
[Recensão a] Pereira, L.; Ribeiro, F. M. 2009 - 0 património genético português: a história humana preservada nos genes
}

\author{
Autor(es): $\quad$ Alvarez, Manuela \\ Publicado por: CIAS - Centro de Investigação em Antropologia e Saúde \\ URL \\ persistente: \\ URI:http://hdl.handle.net/10316.2/28617 \\ DOI: \\ DOI:http://dx.doi.org/10.14195/2182-7982_28_10 \\ Accessed : $\quad$ 26-Apr-2023 11:42:22
}

A navegação consulta e descarregamento dos títulos inseridos nas Bibliotecas Digitais UC Digitalis, UC Pombalina e UC Impactum, pressupõem a aceitação plena e sem reservas dos Termos e Condições de Uso destas Bibliotecas Digitais, disponíveis em https://digitalis.uc.pt/pt-pt/termos.

Conforme exposto nos referidos Termos e Condições de Uso, o descarregamento de títulos de acesso restrito requer uma licença válida de autorização devendo o utilizador aceder ao(s) documento(s) a partir de um endereço de IP da instituição detentora da supramencionada licença.

Ao utilizador é apenas permitido o descarregamento para uso pessoal, pelo que o emprego do(s) título(s) descarregado(s) para outro fim, designadamente comercial, carece de autorização do respetivo autor ou editor da obra.

Na medida em que todas as obras da UC Digitalis se encontram protegidas pelo Código do Direito de Autor e Direitos Conexos e demais legislação aplicável, toda a cópia, parcial ou total, deste documento, nos casos em que é legalmente admitida, deverá conter ou fazer-se acompanhar por este aviso.

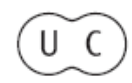




\section{Antropologia Portuguesa}

Departamento de Antropologia | Universidade de Coimbra

Volume $28 \cdot 2011$ 
maiores nesta área científica. Estes são, de resto, os títulos com os quais inevitavelmente comparamos todos os novos livros.

$\mathrm{O}$ atlas de Baxarias e Herrerín bate-se de forma desigual com estes colossos. Cientificamente, o livro é satisfatório e, por vezes, francamente bom. Outras vezes, não: os equívocos gramaticais mesclam-se livremente com as imprecisões científicas e isso, nesta disputa de deuses, é imperdoável.

\section{Francisco Curate}

CIAS - Centro de Investigação em Antropologia e Saúde

Departamento de Ciências da Vida

Faculdade de Ciências e Tecnologia

Universidade de Coimbra, Portugal

f_curate@yahoo.com

Pereira, L.; Ribeiro, F. M. 2009. O património genético português: a história humana preservada nos genes. Lisboa, Gradiva, 202 pp. (Colecção Ciência Aberta; 179). ISBN 9789896163266. €15,00.

Em O património genético português Luísa Pereira e Filipa M. Ribeiro propõem-se revelar a um público alargado, a identidade biológica da população portuguesa actual, temática até agora confinada à literatura científica especializada na área da Genética das Populações Humanas.

Nesta obra, a identidade biológica da população portuguesa é construída a partir da análise e interpretação dos dados da diversidade genética da população actual, juntamente, com dados fornecidos por outros registos do passado, tais como, os registos histórico, arqueológico, paleontológico e paleoclimatológico. Esta necessidade resulta do facto de todos eles, inclusivamente o registo genético, serem selectivos, isto é, revelarem um cenário do passado baseado apenas nos vestígios que sobreviveram até à actualidade.

A divisão do conteúdo deste livro em duas partes reflecte a evolução no tempo e no espaço da população ancestral da Península Ibérica. Na primeira parte, o primeiro capítulo é dedicado ao registo genético e ao modo como ele pode ser utilizado para fazer inferências sobre o passado. Este conhecimento é fundamental para a compreensão do conceito de Património Genético Português.

O genoma humano é uma autobiografia da espécie onde estão registados os principais acontecimentos do nosso passado evolutivo, incluindo os movimentos migratórios dos últimos milhares de anos. A capacidade técnica para ler o genoma 
é relativamente recente, porém, a sua leitura não tem sido uma tarefa fácil porque a variação genética actual é o resultado da acção cumulativa de vários acontecimentos evolutivos e demográficos passados. Extrair informação de um período particular requer que ele seja isolado dos anteriores e dos subsequentes. Para além disso, a selecção natural está sempre presente, influenciando qualquer variação que, potencialmente, afecta a aptidão do fenótipo. Estes obstáculos obrigam à escolha de regiões genómicas selectivamente neutras sempre que se investigam os movimentos migratórios dos últimos milhares de anos. Destas, a região controlo do ADN mitocondrial e o cromossoma Y são, actualmente, as porções do genoma humano consideradas mais informativas em termos geográficos.

Os capítulos 2, 3, 4 e 5 são dedicados à variação genética da população humana ancestral, desde a sua origem até à expansão para fora de África, e a sua chegada à Europa. Neste contexto, a diversidade genética dos portugueses é entendida numa escala europeia para a qual contribuíram importantes acontecimentos demográficos da pré-história, tais como, as expansões populacionais ocorridas após o último Máximo Glacial, no Paleolítico, e a expansão da agricultura a partir do Próximo Oriente, no Neolítico.

O enfoque principal da segunda parte da obra centra-se na variação genética que resultou do impacto das migrações e invasões que ocorreram na Península Ibérica nos últimos 2 milénios, nomeadamente, a residência de longa duração dos Judeus Sefarditas, a ocupação do território por Muçulmanos do Norte de África, e a entrada de escravos provenientes da África subsariana, a partir do século 15. Desde os elementos da linguística, à toponímia e à arquitectura, são muitos os vestígios da miscigenação cultural com os povos que nos visitaram. No capítulo 7, os dados provenientes do registo histórico são cruzados com os vestígios genéticos de modo a construir um cenário provável para a relação entre os invasores e o povo local. Neste cruzamento, é privilegiada a informação veiculada pelo ADN mitocondrial actual. Como este ADN é transmitido, predominantemente, por via materna, o estudo da sua diversidade na população portuguesa permite conhecer apenas uma versão dos acontecimentos - a das mulheres que migraram para o território nacional, que acompanharam os maridos ou que se casaram com homens locais, e que deixaram descendentes.

O capítulo 8 coloca a questão do legado genético ao contrário, isto é, analisa os vestígios deixados pelos portugueses nas diferentes regiões do mundo que visitaram e colonizaram no decurso da expansão marítima. Esta viagem estende-se desde o Norte de África até à Guiné, Moçambique e Angola, incluindo o Brasil e a Índia. 
O vocabulário utilizado em genética das populações é, geralmente, um obstáculo à partilha de informação com um público mais alargado. Por esta razão, produzir uma obra de divulgação nesta área da Antropologia Biológica é um grande desafio. Em O património genético português Luísa Pereira e Filipa M. Ribeiro venceram, claramente, o desafio a que se propuseram.

\section{Manuela Alvarez}

CIAS - Centro de Investigação em Antropologia e Saúde

Departamento de Ciências da Vida

Faculdade de Ciências e Tecnologia

Universidade de Coimbra

alvarez@antrop.uc.pt 